\title{
Histological Study of the Liver of Stingray (Dasyatis sp.)
}

\author{
Ulfaricha Cahya Happyalita \\ Biology Department, Faculty of Science and Technology, UIN Sunan Kalijaga Yogyakarta \\ J1. Marsda Adisucipto No 1 Yogyakarta 55281, Indonesia. Tel. +62-274-540971, Fax. +62-274-519739. \\ Email: ulfaricha@yahoo.com
}

\begin{abstract}
Happyalita U C. 2017. Histological Study of the Liver of Stingray (Dasyatis sp.). Proc Internat Conf Sci Engin 1: 55-57. Exploitation and destruction of nature by humans can accelerate the rate of species extinction and disrupt the ecosystem balance. One of faunas in Indonesia that is currently less populated is stingray (Dasyatis sp.). Research on stingrays has been largely done in terms of ecology, behavior, and diversity. But stingray research, especially in histology, is still relatively rare. In this paper we studied histological structure of Dasyatis sp. liver. Histological preparations of liver stingrays revealed hepatocytes, arterioles, bile ducts, and sinusoids. Hepatocytes or the major cells of the liver constituent have a nucleus, surrounded by a visible cytoplasm.
\end{abstract}

Keywords: Histology, Liver, Stingrays, Dasyatis sp.

\section{INTRODUCTION}

Exploitation and destruction of nature by humans can accelerate the rate of species extinction and disrupt the ecosystem balance. One of the faunas in Indonesia, which is currently less populated, is stingray (Dasyatis sp). In marine waters, stingrays have a very important ecological role, especially as benthic predators, and some aspects of biology that have not been thoroughly studied (Endang, 2009).

In Indonesian waters, stingrays are caught almost all year round. Based on data from the Directorate General of Fisheries, Ministry of Agriculture (1995), production of stingray fish in 1993 reached approximately 35,686 tons. In Indonesia, there are several kinds of stingrays, including Pari Burung (Rhinoptera javanica), Pari Kelapa (Trygon sephen), Pari Kembang (Amphostistius kuhlii), Pari Kampret (Gymnura micrura), Pari Totol (Himantura varnak), Pari Kekeh (Rhynchobatus djiddensis), and Pari Ayam (Dasyatis sephen) (Endang, 2009).

Research on stingrays has been largely done in terms of ecology, behavior, and diversity. Nevertheless research on liver stingrays especially its histology is still very rare. It is interesting to study the histological structure of liver stingray.

\section{MATERIALS AND METHODS}

\section{Time and place}

This research was done on March-May, 2016. This research was conducted in laboratory of Zoology Faculty of Science and Technology UIN Sunan Kalijaga Yogyakarta.

\section{Tools and materials}

The tools used in this research are surgical tools, glassware, microtom, warmer slide, paraffin oven, microscope, slide, cover glass, tweezers, and tissue.
The materials used in this research are stingrays, bouin, chloroform, $(60 \%, 70 \%, 80 \%, 90 \%$, and $96 \%)$ ethanol, toluene, xylol, hematoxylin, eosin and entellan.

\section{Procedure}

Stingrays are sacrified using chloroform and then dissected and parts of the liver are removed and cut with a thickness $0.5 \mathrm{~cm}$. Furthermore the pieces of the liver are washed with physiological salt $(0,9 \% \mathrm{NaCl})$

The organ was fixed using a bouin solution and soaked for 24 hours. The liver organ was then washed using running water for \pm 1 hour and the organ is not broken or broken.

Furthermore, the organ is dehydrated using stratified alcohol (low percentage to high percentage). This process began by immersing the organs in $60 \%$ alcohol for 30 minutes then transferred to $70 \%$ alcohol and soaked for 1 hour. Then it was transferred to $80 \%$ alcohol for 1 hour, and to $90 \%$ alcohol for 1 hour, then transferred to $96 \%$ alcohol for 1 hour. The last process was the organ soaked in alcohol absolute for 1 hour. All treatments are repeated as much as one repetition and are shaken. Then the organ are cleared using toluene for 24 hours.

Then the organ was infiltrated using paraffin: toluene (50:50) for 1 hour in the oven at $65^{\circ} \mathrm{C}$. The organ was then transferred to paraffin I for 2 hours, paraffin II for 3 hours, and paraffin III for 3 hours. Embed animal organs in paraffin blocks. Before embedding, paraffins that have the same liquid point with paraffin used for infiltration thawed first and mold boxes from cartons prepared for organ embed. The liquid paraffin was introduced into the box mold. The organ was subsequently extracted from paraffin III by means of small tweezers and inserted into the box mold and the organ is placed on the bottom of the box mold. Avoid air bubbles in the paraffin. Furthermore, paraffin was left overnight until it becomes hard. 
The next step of sectioning was paraffin blocks mounted on the holder and trimmed with the upper side parallel to the bottom side. Holder mounted on the microtome and done sectioning process by slicing the organs with a thickness of approximately 4-5 micrometers, then taped over the slide that has been smeared with albumin glycerin, then aquades dropped onto slide, then heated above the warmer slide with a temperature of $45 \mathrm{C}$. Then followed by staining process or staining begins with deparaffin process using xylol 1 and 2 for 30 minutes, then dehydration starting from absolute, 96\% alcohol, 90\%, 80\%, 70\%, and 60\% respectively 3 minutes each, then puts aquadest for 3 minute. Stain with hematoxylin solution for 2 minutes. Then washed with running water for 10 minutes. Then immersed into $60 \%$ alcohol. The next process is dyeing with eosin solution which had been added 2 drops of glacial acetic acid for 10 minutes. Furthermore, the rehydration, i.e., alcohol $60 \%, 70 \%, 80 \%, 90 \%$ and $96 \%$ for 3 minutes each. The slide then soaked in absolute alcohol for 3 minute. Clearing was done using xylol 1 and xylol 2 each for 30 minutes. Last step was done by mounting using entellan then closed with a cover glass. Then the organ was labeled and observed using a microscope with magnification of 40x, 100x, and 400x.

\section{RESULTS AND DISCUSSION}

\section{Anatomy}

Stingray liver is the largest organ in the fish body located on abdomen, in the peritoneal cavity. The liver is different from that of mammals. The liver of stingrays is bigger compared with other fish species.

The main structure of the liver is liver cells or hepatocytes. Hepatocytes play a major role in metabolism. These cells are located between sinusoids which is containing blood and bile ducts (Anderson, 1995 in Damayanti, 2010).

An important organ that secretes ingredients for digestion, is a compact, brownish-red gland. It is a gallbladder that serves to accommodate the bile that plays an important role in fat emulsifiers, so the fat can be absorbed by the intestinal wall. The liver organ is composed of liver cells (hepatocytes), including blood capillaries. In general, the liver serves as a place of metabolism of fats and proteins and producing bile. Bile pigment (bilirubin) is the result of liver synthesis derived from hemoglobin. Bilirubin partially absorbed and returned to the liver and partly thrown away with the feces.

\section{Micro Anatomy (Histology)}

Histological slide of the stingrays that have been made are examined under a microscope to determine its structure. Preparations showed hepatocytes, the central nucleus and sinusoids.

According to Robert (1989), fish livers are slightly different from those of mammals. In mammals, there is a central vein as the center of the lobe, whereas in the liver of the Stingrays there is no central vein. Lobulus in fish liver are not clearly seen.

On stingray liver histological observation, there are hepatocytes, arteriola, ductus biliaris, and sinusoids (Alifia and Djawad, 2003). Hepatocytes have a nucleus, surrounded by a visible cytoplasm (Takashima, 1995). Hepatocyte of a fish have a form resembling thin plates or sheets separated by radially dispersed sinusoids (Hadim et al 2002).

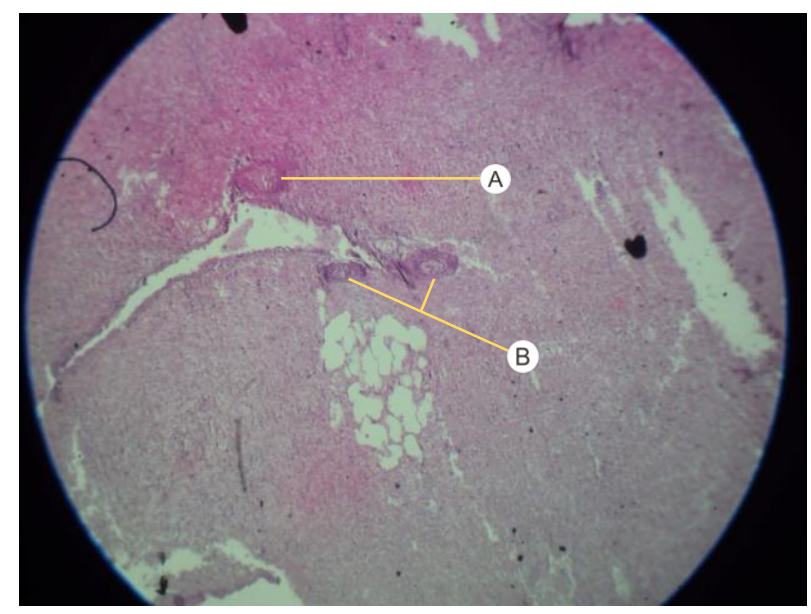

Figure 1. Liver histology of a stingray. A. Arteriole, B. bile ducts.

The gaps between these plates contain capillaries, namely the sinusoids of the liver. Sinusoid contains red blood cells. The function of the sinusoid is as a vessel of oxygen exchange, carbon dioxide, nutrients and toxic substances that are transferred from blood to hepatocytes and from hepatocytes to the blood (Junqueira et al., 1997). Presence of toxic substances in the liver can interference biological enzymes function, as well as affecting the liver histological structure.

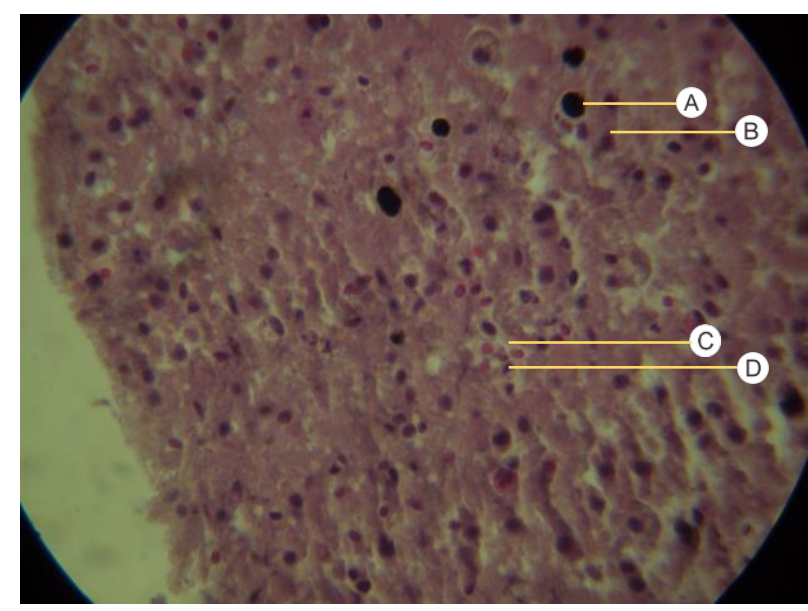

Figure 2. Liver histology of a stingray. A. Hepatocytes. B. Cytoplasm, C. Sinusoid, D. Red Blood Cell. 


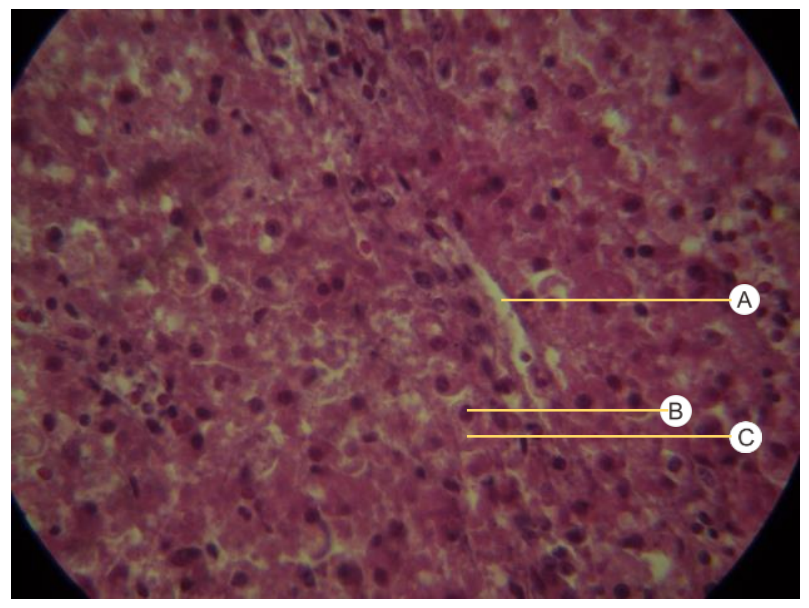

Figure 3. Liver histology of a stingray. A. Sinusoid, B. Hepatocyte. C. Cytoplasm.

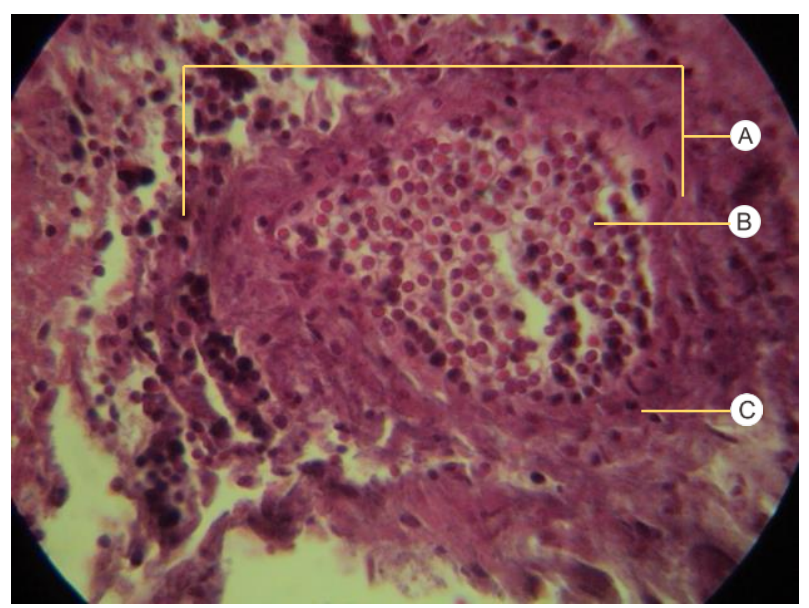

Figure 4. Liver histology of a stingray. A. Arteriole, B. Red Blood Cell, C. Arteriole Wall

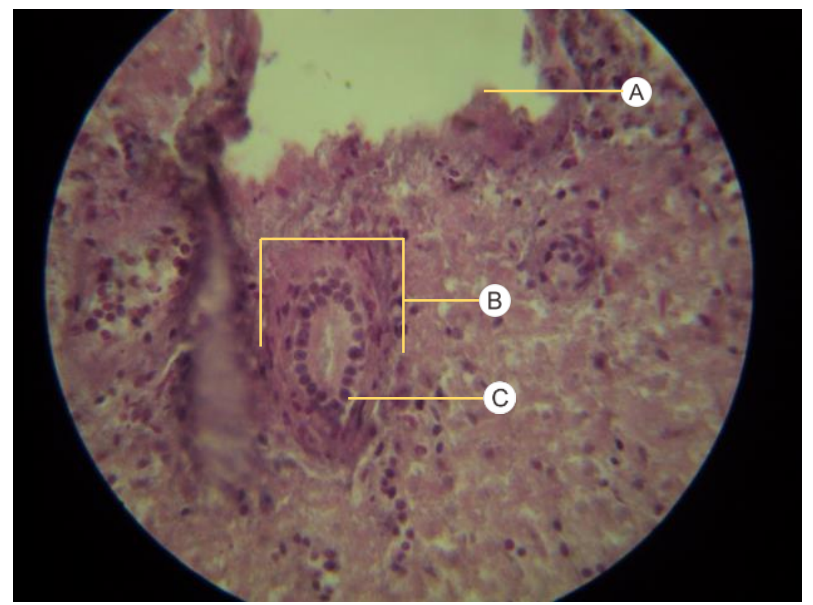

Figure 5. Liver histology of a stingray. A. Connective tissue (serous membrane), B. Ductus biliaris, C. Red Blood Cell.

\section{CONCLUSIONS}

Histologicaly, liver stingray consist of hepatocytes, arterioles, bile ducts, and sinusoids. Hepatocytes or primary cells of the liver constituent have a nucleus, surrounded by a visible cytoplasm. There were not central vein nor lobulus septum observed.

\section{REFERENCES}

Alifia, F dan M.I Djawad. 2003. Kondisi histology Insang dan Organ dalam juvenile ikan bandeng (Chanos chanos forskall) yang tercemar logam timbal $(\mathrm{Pb}) \mathrm{J}$. Sains \& Teknologi.

Damayanti, F.N. 2010. Pengaruh Pencemaran Logam Berat terhadap Kondisi Histologi Ikan Nila (Oreochromis niloticus Linn) dalam Karamba Jaring Apung di Blok Jangari Cirata. Skripsi. Universitas Padjajaran. Jatinegoro.

Endang. 2009. Ikan Pari (Dasyatis sp.). UGM Press. Yogyakarta

Hidayati, D. 2009. Aplikasi Fitoremediasi Polutan dengan Klambang (Salvinia molesta) dan Eceng Gondok (Eichornia crassipies) Pada Air Tercamar Lumpur Lapindo dan Uji Biologis Sebagai Media Pemeliharaan Bandeng (Chanos chanos). Lembaga Penelitian dan Pengabdian Kepada Masyarakat. Skripsi. Institut Teknologi Sepuluh November. Surabaya.

Khaisar O. 2006. Kadar Timah Hitam $(\mathrm{Pb})$ dan Kadmium $(\mathrm{Cd})$ Dalam Air, Sedimen dan Bioskumulasi Serta Respon Histopatologis Organ Ikan Alu-Alu (Sphyraena barracuda) di Perairan Teluk Jakarta (Sekripsi). Fakultas Perikanan dan Kelautan. Bogor. Institut Pertanian Bogor.

Palar, H. 1994. Pencemaran dan Toksikologi Logam Berat. PT Rineka Cipta. Jakarta.

Subandiyono, dan S. Hastuti. 2010. Nutrisi Ikan. Tim Pengajar nutrisi Ikan FPIK Universitas Diponegoro. Yogyakarta.

Takashima, F and Hibiya, T. 1995. An Atlas Of Fish Histology: Hormal and Features. Second Edition. Tokyo. Kondasha Ltd.

Tresnati, J. \& M.I. Djawad. 2012. Effect of lead on gill and liver of Blue Spotted Ray (Dasyatis kuhlii). Journal of Cell and Animal Biology 6(17)

Tresnati, J., M.I. Djawad dan A. S. Bulqish. 2007. Kerusakan Ginjal Ikan Pari Kembung (Dasyatis kuhlii) yang Diakibatkan oleh Logam Berat Timbel (Pb). Jurnal Sains dan Teknologi, Universitas Hasanudin. Makasar. J. Sains \& Teknologi Vol. 7 (3): $153-160$. 
THIS PAGE INTENTIONALLY LEFT BLANK 